\title{
SOME NEW AND RARE EUGLENOPHYCE FROM THE STATE OF SÄO PAULO, SOUTHERN BRAZIL
}

Carlos E. de M. Bicudo ${ }^{1}$ Denise de C. Bicudo ${ }^{1}$

Received in Aug. 29th, 1986. Accepted in Oct. 6th, 1986.

\begin{abstract}
Occurrence is reported from the region of the city of São Paulo, southern Brazil, of two euglenoid flagellates (Euglenophyceae). These are very rare, and thus very poorly known members of the class: Scytomonas major (Berliner) Lemmermann and Scytomonas pusilla Stein var. sarmatica Drez̀epolski. Two species - Gyropaigne brasiliensis C. Bicudo \& D. Bicudo, sp. nov. and Phacus ephippioideus C. Bicudo \& D. Bicudo, sp. nov. - are also described as new to science.
\end{abstract}

Key words: Algae, Euglenophyceae, Gyropaigne, Phacus, Scytomonas, Brazil.

RESUMO - O trabalho documenta o encontro na cidade de São Paulo e arredores, Estado de São Paulo, sul do Brasil, de duas algas de ocorrência rara e conhecimento precário - Scytomonas major (Berliner) Lemmermann e Scytomonas pusilla Stein var. sarmatica Dreżepolski além de outras - Gyropaigne brasiliensis C. Bicudo \& D. Bicudo, sp. nov. e Phacus ephippiotdeus C. Bicudo \& D. Bicudo, sp. nov. - cujas descrições originais são ora apresentadas e feitas suas proposições como novidades para a ciência.

Palavras chaves: Algas, Euglenophyeeae, Gyropaigne, Phacus, Scytomonas, Brasil.

\section{Introduction}

The algae forming the subject of this communication were collected mostly from localities round about the city of São Paulo, in the State of São Paulo, southern Brazil, during the period 1966-1969.

Two of the algae studied were considered to be relatively poorly known members of the algae; two others have been carefully examined and finally described and proposed as new to science.

\section{Gyropatgne Skuja}

The genus was proposed by Skuja, in 1939, based on material he himself collected from a cold water tank of a greenhouse in the Riga University Botanical Garden, Vidzeme, Latvian S.S.R.

Gyropaigne has colourless, biflagellate, ridged, free-swimming, non-metabolic cells. They may be short subcylindrical, fusiform, ovoid, or somewhat elliptical in shape when seen in front view, and radiate when seen from one end. The flagella are inserted at the base of the reservoir. The canal opening is slightly subapical. The periplast is firm, colourless, with a number of pronounced helical keels. The protoplasm is hyaline. Paramylum

\footnotetext{
1Phycology Section, Instituto de Botânica, Caixa postal, 4005, 01000-São Paulo, SP, BRASIL.
} 
granules are numerous. The nucleus is conspicuous and approximately centrally located, or displaced towards the posterior end of the cell.

Nothing is so far known about reproduction in this genus.

Authors as a whole are in agreement concerning the taxonomic position of this genus among the Astasiaceae. BOURRELLY (1985), however, placed Gyropaigne in the Euglenaceae.

The genus includes only 4 species, and it is known from Europe: Latvian S.S.R., France, Ukranian S.S.R., and Switzerland; and from South America: Chile.

The material collected at the São Paulo Botanical Garden has more or less bilateral asymmetrically elliptical cells when seen in front view; the posterior end is usually more acuminate than the anterior end, which is also sometimes more rounded. The end view of the cell is bilaterally compressed, never perfectly circular, with 8 conspicuous helical keels separated by 8 very marked shallow depressions. The reservoir is more or less dropshaped, with the cytostome slightly subapical. The nucleus is central and usually a little displaced towards the lateral margin of the cell. 8 to 10 roundish paramylum granules are commonly seen in the cytoplasm.

The present new species is easily distinguished from the 4 already described by the asymmetrically elliptical shape of the individuals in front view, and by the conspicuously depressed cells when seen from one end. It may be compared to the type-species of the genus, G. kosmos Skuja (SKUJA, 1939: 113, pl. 7, fig. 16-18), from which it is distinct by the shape of the individuals and the vertical view of the cell. Regarding the latter, PRINGSHEIM (1963) and LEEDALE (1967) mention non-flattened cells among the generic characteristics for Gyropaigne. However, Gyropaigne definitely includes species with both flattened and non-flattened cells, since $G$. spiralis (Matvienko) Bourrelly \& Georges and the present $G$. brasiliensis C. Bicudo \& D. Bicudo (particularly the latter) have conspicuously flattened cells (Figure 9).

Gyropaigne brasiliensis C. Bicudo \& D. Bicudo, sp. nov. - Figure 7-9.

Cellulae ellipticae, assymetricae, $37-45 \mu \mathrm{m}$ longae, $18-22 \mu \mathrm{m}$ latae, polo anteriore leviter acuminato vel subtruncato-rotundato, polo posteriore acuminato; ab apice visae bilateraliter compressae; periplastus firmus, hyalinus, 8-carinatus, carinae longistrorsum dispositae, helicoidae; cytoplastus hyalinus, paramylum 8-10 granulis rotundatis munitum.

Typus: HOLOTYPUS, figurae nostrae 7-9.

Origo: Brasilia, Status Sancti Pauli, Municipium Sancti Pauli, Hortus Botanicus, hydrophytoterium, lectus C.E.M. Bicudo, 04.II.1966 (SP).

\section{Phacus Dujardin}

The proposed new species is based on material gathered by one of the authors (CEMB) from an artificial pond in the São Paulo Botanical Garden, in the city of São Paulo.

Individuals are saddle-shaped, with the sides hanging down like the laps of a saddle. The prominent reservoir and the acuminate caudus are placed opposite to each other along the longitudinal axis of the cell. The periplast is longitudinally striate. In the cytoplasm it is possible to observe a number of small, disc-shaped chloroplasts and a large, globose paramylum body. Length of individuals including the caudus $38-45 \mu \mathrm{m}$, maximum breadth including aliform projections $40-50 \mu \mathrm{m}$.

There is another species of Phacus described as havind saddle-shaped cells, i.e. Phacus ephippion Pochmann (POCHMANN, 1942: 208, fig. 120). The latter is based upon a form of $P$. longicauda ((Ehrenberg) Dujardin var. torta Lemmermann reported by 
FRITSCH \& RICH (1928: 76, fig. 25B-F) from samples collected from the Public Gardens of Kimberley, South Africa. Phacus ephippion Pochmann, however, can never be confused with the present $P$. ephippioideus C. Bicudo \& D. Bicudo because the shape of the cell is very distinct for each species, and something of a distinguishing character for the latter.

\section{Phacus ephippioideus C. Bicudo \& D. Bicudo, sp. nov. - Figure 4-6.}

Cellulae subselliformes, $38-45 \mu \mathrm{m}$ longae, $40-50 \mu \mathrm{m}$ latae, appendices alares laterales more equi sellae pendentes, cauda acuminata; stigna conspicuum, ad repositorium dispositum; repositorium conspicuum, secus axem medianum cellulae dispositum; periplastus longistrorsum striatus; paramyli corpusculum uniculum, globosum, grande; chloroplastidii numerosi, discoidei.

Typus: HOLOTYPUS, figurae nostrae 4-6.

Origo: Brasilia, Status Sancti Pauli, Municipium Sancti Pauli, Hortus Botanicus, hydrophytoterium, lectus C.E.M. Bicudo, X.1969 (SP).

\section{Scytomonas Stein}

Scytomonas has colourless, uniflagellate, free-swimming, rigid cells, with a distinct periplast and 1 or 2 contractile vacuoles located at the anterior portion of the cell. The flagellum is very conspicuous and is inserted at the base of the subapical reservoir. MIGNOT (1966) demonstrated that Scytomonas has but a single flagellum, and that there is no evidence at all of the second one in the reservoir. This makes Scytomonas the only euglenoid flagellate to have just one flagellum. The nucleus may be either centrally or posteriorly located in the cell. Pharingeal rod organs were not seen to date. Minute paramylum granules were seen both in $S$. ovatum Silva and in $S$. stene Silva (SILVA, 1953: 348).

Reproduction is by longitudinal division of cells and takes place while they are temporarily immobile. Isogamous sexual reproduction involving conjugation was described by DOBELL (1908). However, as was stated by that same author, the only fact established with certainty is the fusion of motile gametes, since the supposed division of nuclei observed in conjugating cells of Scytomonas is extremely doubtful. The zygote usually remains motile for a certain time, but this time lapse was not made clear in DOBELL (1908). It then divides by fission to produce the new individuals, or rounds up to form thickwalled resting stages (cysts).

The taxonomic position of Scytomonas is somewhat questionable. It was recently placed by LEEDALE (1967) among genera he found to be of doubtful affinity, and according to him, further studies are needed to confirm whether or not these organisms are euglenoid flagellates. However, almost simultaneously MIGNOT (1967) proposed the family Scytomonadaceae to include the single genus Scytomonas, which is characteristic in the possession of only one flagellum, while PRINGSHEIM (1963), on the basis of the holozoic nutrition and on the gliding type of movement displayed by the organisms, placed the genus Scytomonas among the Peranemaceae, as was done before by LEMMERMANN (1913) (among others).

As far as is know, Scytomonas major (Berliner) Lemmerman is only found in the intestinal tract of Lacerta viridis Gessner. Scytomonas pusilla Stein, however, has been found both in the intestinal tract of frogs and toads, and free-living in dirty water. The variety sarmatica of the latter was to date only found in the plankton. 
The two taxa presently reported for São Paulo, Scytomonas major (Berliner) Lemmermann and Scytomonas pusilla Stein var. sarmatica Drez̀epolski, were found living in the plankton of natural ponds rich in organic matter.

Scytomonas major (Berliner) Lemmermann - Figure 3.

In Pascher, Süsswasser-Fl. Deutschl. 2: 168, fig. 333. 1913. central.

Cells elongate-elliptic, broadly rounded at both poles, $40-45 \times 20-25 \mu \mathrm{m}$; nucleus

Hab. - planktonic in a pond at the São Paulo Botanical Garden, São Paulo City, State of São Paulo.

The half dozen specimens of this species we were able to study showed very little variation in size, but with an average about twice the limits given in LEMMERMANN (1913). BERLINER (1909) in the original description of the species, under the combination Copromonas major, does not include measurements.

SILVA (1953: 348) proposed Scytomonas ovatum, the original description of which is very brief and the cell shape in the illustration extremely similar to that of $S$. major (Berliner) Lemmermann. The sole difference between the two species above seems however to be in the measurements, which are ca. $20 \times$ ca. $8 \mu \mathrm{m}$ in $S$. major (Berliner) Lemmermann and $50 \times 20 \mu \mathrm{m}$ in $S$. ovatum Silva. Since $S$. major (Berliner) Lemmermann is an alga of rare occurrence, and as far as we know until now only reported from the original collection, and whose description was copied down in HUBER-PESTALOZZI (1955), we have decided to enlarge the former measurement limits of the species rather than propose a new form or variety within the species. Furthermore, in all other respects the Brazilian specimens seem perfectly to agree with the original description of $S$. major (Berliner) Lemmermann. Consequently, it is very likely that $S$. ovatum Silva will be considered synonymous with $S$. major (Berliner) Lemmermann.

Scytomonas pusilla Stein var. sarmatica Drezèpolski - Figure 1-2.

Kosmos, Warsz. 1925: 254, fig. 180. 1925.

Cells ovoid, $45-50 \times 35-38 \mu \mathrm{m}$; nucleus posterior, very seldom centrally located.

Hab. - planktonic in a small pond by number 3669 of Washington Luiz Avenue, São Paulo City, State of São Paulo.

The plants studied are in perfect agreement with the original description of the variety in DREŻEPOLSKI (1925) except for the measurements. This variety, as is also the case with the preceeding species, seems to be to date only known from the original collection and further reference to that same gathering by HUBER-PESTALOZZI (1955) and STARMACH (1983), which just gives us a pale idea of the variation range of the species. On that basis, we think it would be better to enlarge the original size limits of the variety in order to include those of the Brazilian specimens, rather than propose a new taxon based solely on cell measurements.

\section{Acknowledgements}

The authors wish to express their appreciation to Mrs. Alzira Rossi Mascarenhas, for her help in preparing the Latin diagnoses in this paper, and to Mr. Alasdair G. Burman, for improvement of the English text. 


\section{Bibliographic References}

BERLINER, E. 1909. Flagellatenstudien. Arch. Protistenk., Jena, 15: 297-325.

BOURRELLY, P. 1985. Les algues d'eau douce: initiation à la systématique. Paris: Société Nouvelle des Éditions Boubée. Vol. 3, p. 1-606, pl. 1-139 (edição revista e ampliada).

DOBELL, C.C. 1908. The structure and life history of Copromonas subtilis, nov. gen., nov. sp.: a contribution to our knowledge of the Flagellata. Q. J1 microsc. Sci.: nov. ser., London, 52: 75-120, fig. a-c, $1-48$.

DREŻEPOLKI, R. 1925. Przycznek do znajomósci polskich Euglenin (Supplément à la connaissance des Eugléniens de la Pologne). Kosmos, Warszawa, 50(1A): 173-270, fig. 1-190.

FRITSCH, F.E. \& RICH, F. 1928. Contributions to our knowledge of the freshwater algae of Africa, 7: freshwater algae (exclusive diatoms) from Griqualand West. Trans. R. Soc. S. Afr., Cape Town, $18: 1-92$, fig. $1-32$.

HUBER-PESTALOZZI, G. 1955. Das Phytoplankton des Süsswassers: Systematik und Biologie: Euglenophyceen. Stuttgart: E. Schweizerbart'sche Verlagsbuchhandlung (Nägele u. Obermiller). Vol. $16(4)$, p. ix + 1-606, fig. 1-1136.

LEEDALE, G.F. 1967. Euglenoid flagellates. Englewood Cliffs, N.J.: Prentice Hall, Inc. p. xiii + 1-242, fig. 1-176.

LEMMERMANN, E. 1913. Eugleninae. In PASCHER, A. ed. Die Süsswasser-Flora Deutschlands, Osterreichs und der Schweiz. Jena: Gustav Fischer Verlag. Vol. 2, p. 115-174, fig. 182-377.

MIGNOT, J.-P. 1966. Structure et ultrastructure de quelques Euglénom onadines. Protistologica, Paris, 2:51-117, fig. 1-19. pl. 1-23. tah. 1 .

1967. Affinites des Euglénomonadines et des Chloromonadines: remarques sur la systématique des Euglenida. Protistologica, Paris, 3:25-60, fig. 1-4, tab*1.

POCHMANN, A. 1942. Synopsis der Gattung Phacus. Arch. Protistenk., Jena, 95(2): 81-252, fig. a-w, $1-170$.

PRINGSHEIM, E. 1963. Farblose Algen: ein Beitrag zur Evolutionsforschung. Stuttgart: Gustav Fischer Verlag. p. xi $+1-471$, fig. 1-80.

SILVA, H. 1953. Fifteen new algae. Bull. Torrey bot. Club, New York, 80(4): 342-348, fig. 1-15.

SKUJA, H. 1939. Beitrage zur Algenflora Lettlands, 2. Acta Horti bot. Univ. latv., Riga, 11-12: 41169 , pl. 1-11.

STARMÁCH, K. 1983. Euglenophyta, Eugleniny. In STARMACH, K. \& SIEMIN̂SKA, J. ed. Flora Slodkowodna Polski. Warszawa, Kraków: Państwowe Wydawnictwo Naukowe. Vol. 3, p. 1-594, fig. 1-1412. 

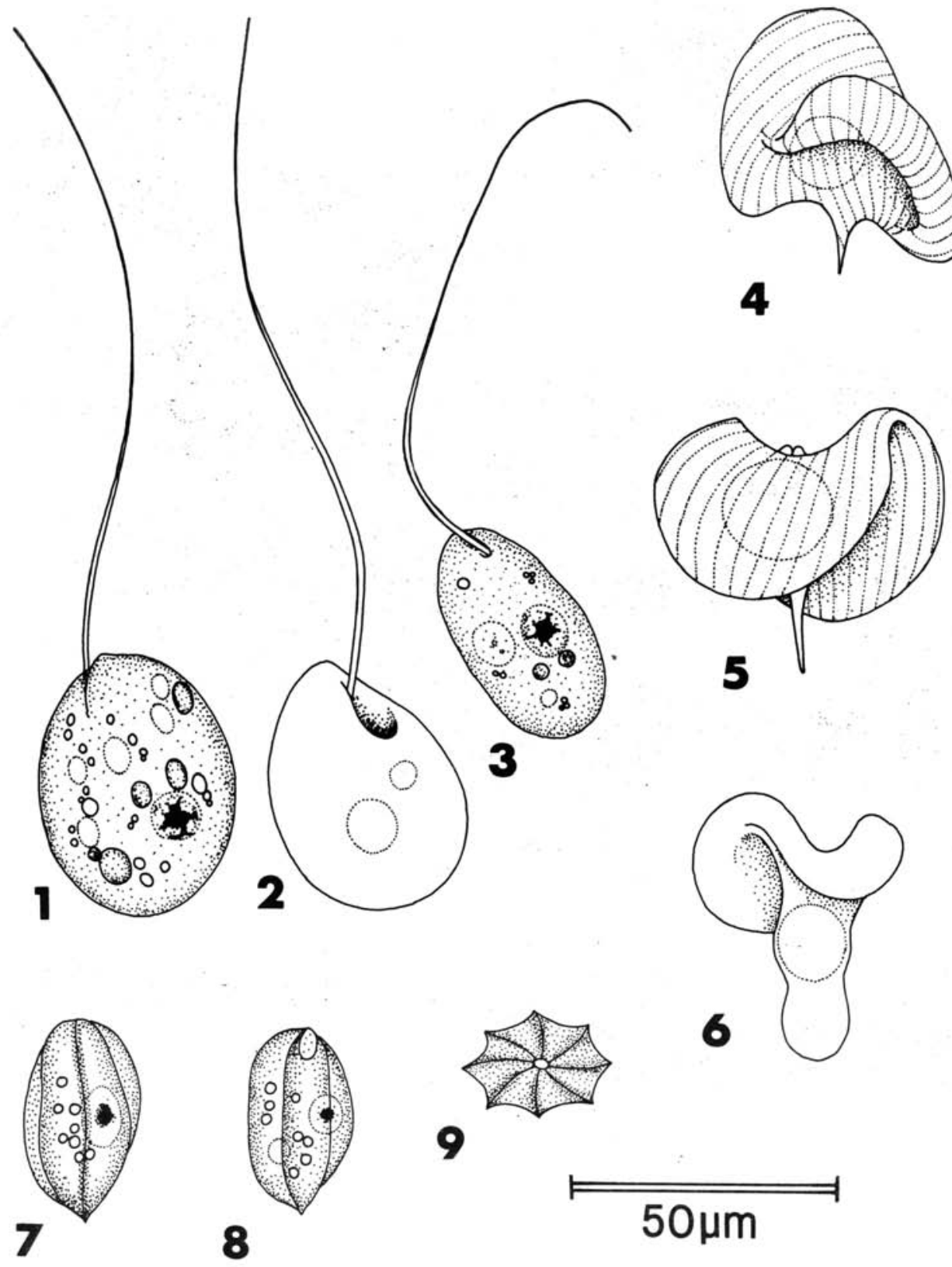

FIGURE 1-2 - Scytomonas pusilla Stein var. sarmatica Drez̀epolski. FIGURE 3 - Scytomonas major (Berliner) Lemmermann. FIGURE 4-6 - Phacus ephippioideus C. Bicudo \&: D. Bicudo, sp. nov.; 5, lateral view; 4,6 , other views. FIGURE 7-9 - Gyropaigne brasiliensis C. Bicudo \& D. Bicudo, sp. nov.: 9 , vertical view. 